\title{
Normas para la protección y cuidado de personas ante la pandemia COVID-19
}

\section{Guidelines for the protection and care of people in the COVID-19 pandemic}

\author{
Roberto Guillermo Calva-y Rodríguez, ${ }^{*,+}$ Alicia Robledo-Galván,* \\ Alfredo Vigueras-Rendón,* Guillermo Yanowsky-Reyes,* Francisco Paredes-Fernández,* \\ Manuel Gil-Vargas, ${ }^{*}$ Reynaldo Michel-Aceves ${ }^{\ddagger}$
}

* Mesa Directiva; $\ddagger$ Coordinador Departamento de Pediatría Social Preventiva, Academia Mexicana de Pediatría, $2019-2021$.

La Academia Mexicana de Pediatría, a través de la Mesa Directiva y el Departamento de Pediatría Social y Preventiva, presenta a la sociedad sus recomendaciones para la protección y cuidado de personas ante la pandemia de COVID-19:

Normas para cuidarte si sospechas* que eres portador del virus

(*presentar síntomas de la enfermedad o estar en contacto con personas con COVID-19)

- La mayoría de las personas que se infectan por el virus pueden presentar síntomas leves de la infección y recuperarse pronto.

- Los síntomas pueden durar unos días.

- Debes seguir alimentándote bien, descansar y tomar muchos líquidos.

- Mantén una adecuada distancia entre los miembros de la familia (1.5 m).

- Tu habitación deberá estar lo más ventilada posible.

- Siempre lleva un cubrebocas plisado en casa.

- No toques el cubrebocas con las manos.

- Lávate las manos cada dos horas.

- $\mathrm{Al}$ ir al baño, sé cuidadoso(a), deposita las heces, el papel y vacía en el inodoro una porción de cloro al $1 \%$.

\footnotetext{
+Correspondencia: RGCR, dr.robertocalvarodriguez@gmail.com Conflicto de intereses: Los autores declaran que no tienen. Citar como: Calva-y Rodríguez RG, Robledo-Galván A, ViguerasRendón A, Yanowsky-Reyes G, Paredes-Fernández F, Gil-Vargas $\mathrm{M}$ et al. Normas para la protección y cuidado de personas ante la pandemia COVID-19. Rev Mex Pediatr. 2020; 87(4): 159-160. https://dx.doi.org/10.35366/95829
}

- Seca las manos con una toalla pequeña de tela, cambiándola y lavándola con frecuencia.

- Cúbrete la boca y la nariz al estornudar y toser con pañuelos o toallas de papel, deséchalos en un lugar especial; posteriormente lávate las manos.

- Si eres mamá, puedes seguir dándole el pecho a tu hijo, utilizando adecuadamente el cubrebocas, lavándote las manos y los pechos con frecuencia.

- No compartas con nadie objetos personales, por ejemplo, cepillo de dientes, esponjas, toallas.

- Los cubiertos, platos, ropa personal y sábanas se deberán lavar con agua y jabón.

- Desinfecta celulares, tabletas y computadoras con gel hidroalcohólico.

- No se recomienda utilizar joyas, relojes, pulseras, aretes, etcétera.

- Las pruebas para la detección de COVID-19, como PCR y anticuerpos, sólo deberás realizarlas cuando tu médico lo indique.

- Una sola persona debe salir a las compras de alimentos y a la farmacia.

- Si presentas algún factor de riesgo como diabetes, hipertensión arterial, sobrepeso/obesidad, o enfermedad cardiovascular, hepática, pulmonar, algún tipo de problema inmunológico, debes aislarte completamente.

- Evita el transporte público.

- No aceptes visitas, ni salgas a la calle.

- En lo posible, cuida tu salud mental mediante la realización de ejercicio dentro de casa, practica la lectura, conversa por teléfono o videollamadas con familia y amigos. Evita escuchar o estar al tanto de noticias sobre COVID-19 en cualquier medio de 
comunicación; recuerda que en redes sociales puede haber información poco confiable.

Normas para cuidarte si eres portador* del virus (*por confirmación de enfermedad por PCR, o diagnosticada por médico)

- Mantente en una habitación individual sólo para ti.

- Procura que esté lo más ventilada posible.

- No debes visitar otras habitaciones de tu vivienda

- Siempre utiliza cubrebocas plisado.

- No toques el cubrebocas con las manos.

- Lávate las manos cada dos horas.

- Al ir al baño, sé cuidadoso, deposita las heces, el papel y vacía en el inodoro una porción de cloro al 1\%.

- Seca las manos con una toalla pequeña de tela, cambiándola y lavándola con frecuencia.

- Cúbrete la boca y la nariz al estornudar y toser con pañuelos o toallas de papel, deséchalos en un lugar especial; posteriormente lávate las manos.

- Si eres mamá, puedes seguir dándole el pecho a tu hijo, utilizando adecuadamente el cubrebocas, lavándote las manos y los pechos con frecuencia.

- No compartas con nadie objetos personales, por ejemplo, cepillo de dientes, esponjas, toallas.

- Desinfecta celulares, tabletas y computadoras que utilices con gel hidroalcohólico.

- Las pruebas para la detección de COVID-19, como PCR y anticuerpos, sólo deberás realizarlas cuando tu médico lo indique.

- Mantente en casa hasta que tu médico te lo indique.

- No utilices joyas, relojes, pulseras, aretes, etcétera.

Normas para cuidar enfermos con COVID-19* (*por confirmación de enfermedad por PCR, o diagnosticada por médico)
- Una sola persona debe cuidar al enfermo, quien debe gozar de buena salud.

- No permitas visitas por ningún motivo.

- Si hay más habitantes, deben permanecer en habitaciones distintas.

- En todo momento utiliza cubrebocas, con mayor razón al estar junto al enfermo.

- No toques ni manipules el cubrebocas.

- Lávate las manos después de cualquier contacto con el enfermo o sus objetos cercanos.

- Lávate las manos antes y después de preparar sus alimentos.

- Se pueden utilizar guantes desechables para manipular objetos que tengan secreciones del enfermo, desechándolos adecuadamente.

- Limpia con solución de cloro al 1\% las superficies como el piso, baño, inodoro, mesa de noche y la estructura de la cama.

- Limpia con gel hidroalcohólico al 70\% los muebles de uso común como escritorios, mesas, sillas.

- La ropa del enfermo se puede colocar en una bolsa o bandeja especial hasta el momento de lavarla.

- Lavar con agua y jabón la ropa de uso personal, sábanas y toallas.

- No debes sacudir la ropa.

- Evita el contacto directo con la piel y ropa de los materiales contaminados; de ser posible, emplea guantes desechables.

- Todas las personas que convivan en el domicilio del enfermo, son consideradas "contactos en observación y aislamiento" hasta después de 14 días.

- Si alguno de los contactos presenta en ese lapso síntomas asociados con COVID-19 (fiebre, tos, cefalea, etcétera), avisa inmediatamente a su médico y sigue las Normas para cuidarte si sospechas que eres portador del virus, señaladas al principio de este documento. 